DOI: 10.17707/AgricultForest.61.1.37

\author{
Jelena LAZAREVIĆ, \\ Dragica VILOTIĆ, Nenad KE $\check{C ̆}^{1}$
}

\title{
MYCORRHIZATION AND USE OF SUPERABSORBENT POLYMERS IN TARGETED PRODUCTION OF HARDWOODS PLANTING MATERIAL
}

\begin{abstract}
SUMMARY
Production of forest and ornamental trees seedlings is one of the most important areas concerning forestry techniques in whole, because successful afforestation, plant survival and fast development of seedlings depend on their quality. It is of special importance for South-eastern European (SEE) region, due to unfavourable environmental conditions: prevailing high summer temperatures of air and soil, low humidity and low precipitation during growing season. Besides, nursery production in open field conditions in Submediterranean and Mediterranean region is faced with the same problems.

Here we were examining a combined effect of seedling mycorrhization and usage of polymers during the nursery production of Quercus ilex L. and Acer dasycarpum Enhr. seedlings in open field conditions for three years. The objectives of the study were: 1) to examine the efficiency of ECM commercial product on $Q$. ilex seedlings growth; 2) to compare the efficiency of different concentrations of VAM commercial product on A. dasycarpum seedlings growth; 3 ) to compare combined effect of seedling mycorrhization and usage of superabsorbent polymers on growth of $Q$. ilex and $A$. dasycarpum seedlings.

Mycorrhization and application of superabsorbent polymers during the seedlings growth in nursery were effective method for achieving better quality of $Q$. ilex and $A$. dasycarpum seedlings. Mycorrhization of $Q$. ilex seedlings with 1 $\mathrm{ml}$ of ectomycorrhizal inoculum $\left(10^{7}\right.$ propagules $)$ was effective, while validity of polymer application is still under the study. Optimal application dose of VA mycorrhizal inoculum for $A$. dasycarpum was determined on $7.5 \mathrm{ml} / \mathrm{seedling}$ (c.ca 750 infective propagula/plant). The increase of $A$. dasycarpum plant size was evident (1.5 times compared to untreated), and in combination with polymers it was more than 2 times.
\end{abstract}

Keywords: hardwoods seedlings, mycorrhization, superabsorbent polymers, Quercus ilex, Acer dasycarpum.

\footnotetext{
1 Jelena LAZAREVIĆ, (corresponding author: ena.lazarevic@gmail.com), University of Montenegro, Biotechnical faculty, Mihaila Lalića 1, 81000 Podgorica, MONTENEGRO; Dragica VILOTIĆ, Nenad KEČA, University of Belgrade, Facultyof Forestry, Kneza Višeslava 1, 11030 Belgrade, SERBIA.
}

Notes: The authors declare that they have no conflicts of interest. Authorship Form signed online. 


\section{INTRODUCTION}

Successful afforestation, plant survival and fast development of seedlings depend on their quality. Hence, seedling production is one of the most important areas concerning forestry techniques in whole (Claro et al., 1998). For Southeastern European (SEE) region, nursery practices are being focused on the production of seedlings for improving afforestation under the harsh environmental conditions (Claro et al., 1998; Šijačić-Nikolić et al., 2010). Due to prevailing high summer temperatures of air and soil, low humidity and low precipitation during growing season application of modern technologies in nursery production, also as in reforestation of ecologically unfavourable sites is required (Vilotić and Šijačić-Nikolić, 2009).

The seedling quality is being assessed by the evaluation of both morphological and physiological parameters which allow an anticipation of the success of the field establishment (Claro et al., 1998). Seedling mycorrhization controlled inoculation of seedlings with chosen mycorrhizal fungi in forest nurseries, is thought to be among the most important tools for achieving higher seedling vigour and consequently quality, due to fact that mycorrhiza improves the mineral nutrition, growth and adaptation of forest trees (Molina, 1979; Pera and Parlade 2005; Rincon et al., 2005; Ruiz-Diez et al., 2006; Rincon et al., 2007). It ameliorates the physiological status on seedlings mainly by improving water and nutrient uptake from the soil and plays an important role in the protection of plants against environmental stress factors such as drought, pathogenic agents or heavy metal pollutions (Smith and Read, 1997; Menkis, 2005). Two major mycorrhizal types that prevail among forest trees are: ectomycorrhiza (ECM), formed with the important coniferous species of Pinaceae and hardwoods in the Fagaceae, Salicaceae and Betulaceae, and vesicular-arbuscular mycorrhiza (VAM), common on the other hardwoods, particularly on Acer spp, Fraxinus spp., etc. (Castelano and Molina, 1989), also as in agriculture - for viticulture production, fruit growing and crop farming (Bathlenfalvay, 1992).

Superabsorbent polymers, as artificially produced substances which are able to absorb the contacted water, retaining it when not available in the environment, were diversely applied in agriculture (Dragičević et al., 2008), also as for stimulation of establishment and growth of seedlings in alley, shelterbelts and in reforestation of difficult and degraded terrains (Vilotić and Šijačić-Nikolić 2009, Landis and Haase, 2012).

Here we were examining a combined effect of seedling mycorrhization and usage of polymers during the nursery production of Quercus ilex L. and Acer dasycarpum Enhr. seedlings in open field conditions, for three years.

Quercus ilex is a characteristic evergreen oak species in Mediterranean basin (Jovanović, 2007; Scarascia-Mugnozza et al., 2000), where it's being widely used in forest regeneration programs in many countries (Cocobardo et al., 2014; Scarascia-Mugnozza et al., 2000; Sánchez-Andrés et al., 2006.), and also as ornamental tree (Vukićević, 1974). Artificially inoculated (mycorrhized) $Q$. 
ilex seedlings could be used in afforestation trails on ecologically unfavourable sites in Mediterranean and Submediterranean region, and also for purpose of urban greening.

Acer dasycarpum has a native range in North America. Nowadays, it is widely used and cultivated as an ornamental species in different climates, including continental and Mediterranean, because of its rapid growth and ease of propagation and transplanting. It is highly tolerant on urban situations (air pollution), and is frequently planted in alleys. Although it is naturally found near water, it can grow on drier ground if planted there (Jovanović, 2007).

The objectives of the study were: 1) to examine the efficiency of ECM commercial product on $Q$. ilex seedlings growth, 1 and 3 years after application; 2) to compare the efficiency of different concentrations of VAM commercial product on $A$. dasycarpum seedlings growth, 1 and 3 years after application; 3) to compare combined effect of seedling mycorrhization and usage of superabsorbent polymers on growth of $Q$. ilex and A. dasycarpum seedlings during 3 years.

\section{Plant material}

\section{MATERIAL AND METHODS}

Quercus ilex seeds (acorn) were collected in Podgorica (Montenegro), while Acer dasycarpum were collected in Belgrade (Serbia). The seeds were soaked in water overnight and surface sterilized with $3 \% \mathrm{H}_{2} \mathrm{O}_{2}$ for $30 \mathrm{~min}$, and then rinsed with tap water, dried and sowed (Landis, 1989).

\section{Fungal inocula (and inoculation) and polymers tested}

Commercial mycorrizal inoculum was used for seedling inoculation. Quercus ilex were inoculated with Aegis-Ecto, (Sygenta, Spain), composed of Rhizopogon sp., Pisolithus sp., Scleroderma sp. (1g of inoculum contains $10^{7}$ spores). The trays were filled with inoculated substrata $(1 \mathrm{~g} /$ plant according to the manufacturer instruction) and sown with $Q$. ilex seeds.

Acer dasycarpum was inoculated with vesicular-arbuscular mycorrhizal inoculums Aegis, Sygenta (Spain), composed of Glomes intraradices N.C. Schenck\& G.S. Sm and Glomes mosseae T.H. Nicolson et Gerd propagula (100 infective propagula/ $1 \mathrm{ml}$ ). Inoculation of $A$. dasycarpum with Aegis was applied during the replanting of plants in plastic pots, three weeks after seed sowing, with three different inoculation doses 5, 7.5, 10, $\mathrm{ml}$ of VA product/plant).

The following superabsorbent polymer was tested: Water retainer/polymer -Hydro absorption rate between 250 and 350 in powder. The basic characteristic of this polymer is organic origin, ability to absorb and retain water about 300 times more than its own weight, inactivity from the chemical aspect, neutral $\mathrm{pH}$, capacity for remaining in the soil up to 3 years and capacity to decomposition into organic elements available to the plants. Superabsorbent polymers were applied in $2^{\text {nd }}$ year of seedling growth, during replanting of plants. 


\section{Planting and maintenance in $1^{\text {st }}$ growing season}

Quercus ilex seeds were sown in inoculated substrata (peat/send/perlit, 3:2:1) in plastic trays ("Bosna-plast" c.ca $180 \mathrm{ml} /$ cell). Preventive treatment with Captan 80 WG (Arista LifeScience, EU) in conc. $0.3 \%$ was done after sowing.

Acer dasycarpum seeds were sown in woody boxes. Preventive treatment with Mankogal-80 (Galenika, Serbia) in conc. $0.25 \%$ was done after sowing.

In three week period the plants were replanted in 0.51 pots. Inoculation of substrate was done by adding of appropriate amount of inocula in substrate (peat: send: perlit, 3:2:1) close to plant's root.

Seed sowing, germination, and initial plant development (from sowing to replanting and one week more) were conducted under glass and, later, in open field conditions. The plants were shaded or partly shaded May-August, watered daily, and up to three times per week April-September. A water soluble fertilizer Polyfeed 17:10:27 was applied by adding it (c.ca $5 \mathrm{~g}$ ) to the plant rhizosphere 4 times during the season.

\section{Maintenance in $2^{\text {nd }}$ and $3^{\text {rd }}$ growing season:}

During the next year $Q$. ilex and A. dasycarpum were replanted in 2.51 plastic bags, and superabsorbent polymers were added in substrate (peat: send: perlit, 3:2:1) over and close to plant's root. The plants were shaded or partly shaded May-August, watered daily, and up to three times per week AprilSeptember. A water soluble fertilizer Polyfeed 17:10:27 was applied by adding it (c.ca $5 \mathrm{~g}$ ) to the plant rhizosphere 6 times during the season.

\section{Experimental site conditions}

The general climatic parameters for Podgorica could be summarized as follows: average year temperature of $15.5^{\circ} \mathrm{C}$, with average seasonal temperatures of $14.3^{\circ} \mathrm{C}$ in spring, $25.1^{\circ} \mathrm{C}$ in summer (very hot), $16.0^{\circ} \mathrm{C}$ in autumn and $6.2^{\circ} \mathrm{C}$ in winter (mild). Average annual precipitation is $1,637.4 \mathrm{~mm}$, but summer precipitation is only $10 \%$ of the total, with only $2 \%$ in July. Average yearly humidity is $64.7 \%$, minimally $51.2 \%$ in July. Average annual duration of sunlight is $2,477.1 \mathrm{~h}$, with $10.1 \mathrm{~h}$ daily during the summer months $(69.1 \%$ of possible) (Burić et al., 2007) (data source: Hydrological and Meteorological Service of Montenegro).

\section{Experimental design:}

During 1 st growing season, mycorrhizal synthesis was performed on $Q$. ilex and $A$. dasycarpum seedlings. At least 40 plants per treatment were inoculated. In next $\left(2^{\text {nd }}\right)$ growing season plants were replanted in bigger volume plastic bags. Treatments were divided, and one half of seedlings from all treatments stayed as before, and in the other half superabsorbent polymers were added ( $5 \mathrm{ml}$ per plant). Performed treatments in $1^{\text {st }}$ and $2^{\text {nd }}$ growing season were shown in Table 1. 
Stem high and root collar diameter were measured on all seedlings at the end of each growing season (at least 12 seedlings per treatment), and dry weight on 5 seedlings at the end of first and third growing season. The roots were washed free of substrate, and the plants were measured for stem height $(\mathrm{mm})$ and root collar diameter $(\mathrm{mm})$. The one year old seedling shoots and roots were ovendried at $65^{\circ} \mathrm{C}, 18 \mathrm{~h}$, while tree-years old seedlings were oven-dried on $80^{\circ} \mathrm{C}$ for $72 \mathrm{~h}$, to obtain the total dry weight, measured to $10^{-4} \mathrm{~g}$ accuracy. Root vs. shoot ratio was calculated. Rough visual quantitative assessment of ectomycorrhiza was done for $Q$. ilex seedlings.

Table 1 . Treatments on $Q$. ilex and $A$. dasycarpum seedlings performed in $1^{\text {st }}$ and $2^{\text {nd }}$ growing season

\begin{tabular}{|c|c|c|}
\hline \multirow[t]{3}{*}{ Plant species } & \multicolumn{2}{|c|}{ Treatments } \\
\hline & $1^{\text {st }}$ year & $2^{\text {nd }}$ year \\
\hline & mycorrhization & $\begin{array}{l}\text { superabsorbent } \\
\text { polymers }\end{array}$ \\
\hline \multirow{3}{*}{$\begin{array}{l}\stackrel{\vec{u}}{=} \\
\dot{0}\end{array}$} & \multirow{2}{*}{ Aegis-Ecto $10^{7}$ spores/plant } & no \\
\hline & & $5 \mathrm{ml}$ \\
\hline & \multicolumn{2}{|c|}{ water control } \\
\hline \multirow{7}{*}{ 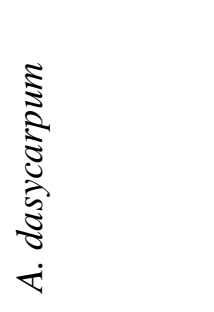 } & \multirow{2}{*}{ Aegis $5 \mathrm{ml} / \mathrm{plant}$} & no \\
\hline & & $5 \mathrm{ml}$ \\
\hline & \multirow{2}{*}{ Aegis $7.5 \mathrm{ml} / \mathrm{plant}$} & no \\
\hline & & $5 \mathrm{ml}$ \\
\hline & \multirow{2}{*}{ Aegis $10 \mathrm{ml} / \mathrm{plant}$} & no \\
\hline & & $5 \mathrm{ml}$ \\
\hline & \multicolumn{2}{|c|}{ water control } \\
\hline
\end{tabular}

\section{Statistical analysis}

Data from the treatments were analyzed by one-way analysis of variance (ANOVA), and significant differences among treatments were separated by Tukey's B test $(\mathrm{p}<0.05)$. Statistical analysis was performed with SPSS 10.0 for Windows (SPSS Inc., Chicago, USA).

\section{RESULTS \\ Seed germination and plant growth in $1^{\text {st }}$ growing season (in treatment with mycorrhizal inoculum)}

Quercus ilex seed germination started after 28 days, and in a 45 day period, about $90 \%$ of the seeds had germinated. The percentage of seedling survival during the first growing season was higher than $85 \%$, but c.ca $60 \%$ survived till the end of third growing season. $Q$. ilex seedling's growth characteristics after the first growing season were shown in Table 2.

The $Q$. ilex seedlings treated with Aegis-Ecto displayed greater height and overall mass than the untreated seedlings. Development of mycorrhiza on the 
roots of the treated seedlings was developed, according the mantle and extraradical mycelium presence and evaluated as moderate.

Table 2. Quercus ilex seedling growth characteristics and ectomycorrhiza development after the $1^{\text {st }}$ growing season after inoculation with Aegis-Ecto ( $10^{7}$ spores per plant, $1 \mathrm{~g}$ of inoculum)

\begin{tabular}{|c|c|c|c|c|c|c|c|}
\hline $\begin{array}{c}\text { Aegis } \\
\text { Ecto }\end{array}$ & $\begin{array}{c}\text { Collar root } \\
\text { diameter }\end{array}$ & Shoot height & $\begin{array}{c}\text { Shoot dry } \\
\text { weight }\end{array}$ & $\begin{array}{c}\text { Leaves dry } \\
\text { weight }\end{array}$ & $\begin{array}{c}\text { Root dry } \\
\text { weight }\end{array}$ & s/r & ECM \\
\cline { 2 - 5 } & \multicolumn{2}{|c|}{$10^{-3} \mathrm{~m}$} & \multicolumn{2}{|c|}{$\mathrm{g}$} & & \\
\hline 0 & $2.21 \pm 0.27^{\mathrm{a}}$ & $107.8 \pm 18.6^{\mathrm{a}}$ & $0.41 \pm 0.17^{\mathrm{a}}$ & $0.17 \pm 0.07^{\mathrm{a}}$ & $0.23 \pm 0.10 \mathrm{a}$ & $1.89 \pm 0.57^{\mathrm{a}}$ & - \\
\hline $\begin{array}{c}\mathrm{T} \\
\left(10^{7} \mathrm{sp} / \mathrm{pl}\right)\end{array}$ & $2.42 \pm 0.14^{\mathrm{a}}$ & $145.0 \pm 34.2^{\mathrm{b}}$ & $0.73 \pm 0.19^{\mathrm{b}}$ & $0.37 \pm 0.15^{\mathrm{b}}$ & $0.35 \pm 0.08^{\mathrm{b}}$ & $2.15 \pm 0.7^{\mathrm{a}}$ & + \\
\hline
\end{tabular}

Values (mean \pm standard deviation); different letters in column indicate significant differences according to Tukey's B test $(p<0.05)$. S/R: shoot/root ratio; ECM: ectomycorrhizal development on seedling roots.

Acer dasycarpum's seed germination started after 10 days, and in a 21 day period, about $75 \%$ of the seeds germinated. The percentage of seedling survival during the test was higher than 90\%. A. dasycarpum seedlings' growth characteristics after the first growing season after inoculation with Aegis were shown in Table 3.

Table 3. Acer dasycarpum seedling growth characteristics after the $1^{\text {st }}$ growing season after inoculation with different inoculation rates of Aegis

\begin{tabular}{|c|c|c|c|c|c|}
\hline $\begin{array}{c}\text { Aegis } \\
(\mathrm{ml})\end{array}$ & $\begin{array}{c}\text { Collar root } \\
\text { diameter }\left(10^{-3} \mathrm{~m}\right)\end{array}$ & $\begin{array}{c}\text { Shoot height } \\
\left(10^{-3} \mathrm{~m}\right)\end{array}$ & $\begin{array}{c}\text { Shoot dry } \\
\text { weight }(\mathrm{g})\end{array}$ & $\begin{array}{c}\text { Root dry } \\
\text { weight }(\mathrm{g})\end{array}$ & S/R \\
\hline 0 & $3.9 \pm 1.1^{\mathrm{a}}$ & $305.3 \pm 65.2^{\mathrm{a}}$ & $0.88 \pm 0.29^{\mathrm{a}}$ & $0.62 \pm 0.15^{\mathrm{a}}$ & $1.51 \pm 0.72^{\mathrm{a}}$ \\
\hline 5 & $3.4 \pm 0.5^{\mathrm{a}}$ & $392.7 \pm 57.3^{\mathrm{b}}$ & $0.81 \pm 0.11^{\mathrm{a}}$ & $0.61 \pm 0.12^{\mathrm{a}}$ & $1.40 \pm 0.13^{\mathrm{a}}$ \\
\hline 7.5 & $6.1 \pm 0.5^{\mathrm{a}}$ & $480.0 \pm 82.8^{\mathrm{c}}$ & $1.54 \pm 0.30^{\mathrm{b}}$ & $1.03 \pm 0.15^{\mathrm{b}}$ & $1.50 \pm 0.15^{\mathrm{a}}$ \\
\hline 10 & $4.9 \pm 0.3^{\mathrm{a}}$ & $420.8 \pm 60.4^{\mathrm{bc}}$ & $1.71 \pm 0.31^{\mathrm{b}}$ & $1.39 \pm 0.22^{\mathrm{c}}$ & $1.23 \pm 0.12^{\mathrm{a}}$ \\
\hline
\end{tabular}

Values (mean \pm standard deviation); different letters in column indicate significant differences according to Tukey's B test $(p<0.05)$. S/R: shoot/root ratio.

Development of $A$. dasycarpum seedlings was unequal. Deviation in size of treated and control seedlings are big, but it is obvious that seedlings treated with Aegis displayed greater height and overall mass than the untreated seedlings. The best high of seedlings is achieved with inoculation rate of $7.5 \mathrm{~g}$ of inoculum, while the best root development is achieved after application of $10 \mathrm{ml}$ of mycorrhzal inoculums. 


\section{Plant growth after $3^{\text {rd }}$ growing season (in treatment with mycorrhizal inoculum and superabsorbent polymers)}

Quercus ilex seedlings' growth characteristics after the third growing season after inoculation with Aegis-Ecto and application of superabsorbent polymers are shown in Table 4.

Table 4. Quercus ilex seedling growth characteristics and ectomycorrhiza development after the $3^{\text {rd }}$ growing season after inoculation with Aegis-Ecto and application of superabsorbent polymers

\begin{tabular}{|c|c|c|c|c|c|c|c|}
\hline Treatment & $\begin{array}{c}\text { Collar root } \\
\text { diameter } \\
\left(10^{-3} \mathrm{~m}\right)\end{array}$ & $\begin{array}{c}\text { Shoot height } \\
\left(10^{-3} \mathrm{~m}\right)\end{array}$ & $\begin{array}{c}\text { Shoot dry } \\
\text { weight }(\mathrm{g})\end{array}$ & $\begin{array}{c}\text { Leaves dry } \\
\text { weight }(\mathrm{g})\end{array}$ & $\begin{array}{c}\text { Root dry } \\
\text { weight }(\mathrm{g})\end{array}$ & S/R & $\begin{array}{c}\text { EC } \\
\mathrm{M}\end{array}$ \\
\hline 0 & $6.36 \pm 0.56^{\mathrm{b}}$ & $450.1 \pm 61.3^{\mathrm{a}}$ & $7.88 \pm 0.39^{\mathrm{b}}$ & $3.78 \pm 0.57^{\mathrm{ab}}$ & $4.89 \pm 0.3^{\mathrm{a}}$ & $1.61 \pm 0.19^{\mathrm{a}}$ & $*$ \\
\hline $0+\mathrm{P}$ & $5.45 \pm 0.33^{\mathrm{a}}$ & $480.0 \pm 51.2^{\mathrm{a}}$ & $6.26 \pm 0.65^{\mathrm{a}}$ & $3.52 \pm 0.40^{\mathrm{a}}$ & $3.82 \pm 0.35^{\mathrm{a}}$ & $1.63 \pm 0.23^{\mathrm{a}}$ & $*$ \\
\hline $\mathrm{T}$ & $6.40 \pm 0.42^{\mathrm{b}}$ & $583.4 \pm 62.9^{\mathrm{b}}$ & $9.51 \pm 0.75^{\mathrm{c}}$ & $4.41 \pm 0.77^{\mathrm{b}}$ & $5.82 \pm 0.84^{\mathrm{b}}$ & $1.63 \pm 0.21^{\mathrm{a}}$ & ++ \\
\hline $\mathrm{T}+\mathrm{P}$ & $6.15 \pm 0.37^{\mathrm{b}}$ & $511.3 \pm 39.3^{\mathrm{a}}$ & $7.05 \pm 0.72^{\mathrm{b}}$ & $3.51 \pm 0.82^{\mathrm{a}}$ & $4.36 \pm 0.29^{\mathrm{a}}$ & $1.62 \pm 0.18^{\mathrm{a}}$ & $+^{*}$ \\
\hline
\end{tabular}

Values (mean \pm standard deviation); different letters in column indicate significant differences according to Tukey's B test $(p<0.05)$. S/R: shoot/root ratio; ECM: ectomycorrhizal development on seedling roots.

+ presence, ${ }^{*}$ weak presence of foreign ectomycorrhiza.

The percentage of mycorrhizal rootlets in the control $Q$. ilex seedlings was bigger than $50 \%$. Foreign ectomycorrhizas were also present on some parts of the rootlets $(10-30 \%)$.

Development of $Q$. ilex seedlings three years after sowing and mycorrhization and two years after application of superabsorbent polymers was unequal and with no regularity in plants' growth. The best developed were the seedlings treated only with ectomycorrhizal inoculums. Untreated seedlings showed a better growth and root development than seedlings in treatments where polymers were added. In treatments with polymers, seedling roots were less haired and slightly reduced. It is not clear if the relatively poorer root morphology in those treatments was a consequence of polymer application, or it was caused by some other agent affecting root development during the 3 years of plant growing in open field conditions.

Three years after mycorrization and two years after application of superabsorbent polymers on A. dasycarpum seedlings, mycorrhized seedlings were better developed than control ones. Addition of $5 \mathrm{ml}$ of mycorrhizal inoculum was not effective, but 7.5 and $10 \mathrm{ml}$ of inoculum had a significant influence on growth of plant root and shoot as well. Addition of superabsorbent polymers also exhibited a positive effect on plant growth, especially in case of mycorrhized seedlings (Table 5.) 
Table 5. Acer dasycarpum seedling growth characteristics after the $3^{\text {rd }}$ growing season after inoculation with different inoculation rates of Aegis and application of superabsorbent polymers

\begin{tabular}{|c|c|c|c|c|c|}
\hline Treatment & $\begin{array}{c}\text { Collar root } \\
\text { diameter } \\
\left(10^{-3} \mathrm{~m}\right)\end{array}$ & $\begin{array}{c}\text { Shoot height } \\
\left(10^{-3} \mathrm{~m}\right)\end{array}$ & $\begin{array}{c}\text { Shoot dry } \\
\text { weight }(\mathrm{g})\end{array}$ & $\begin{array}{c}\text { Root dry } \\
\text { weight }(\mathrm{g})\end{array}$ & $\mathrm{S} / \mathrm{R}$ \\
\hline 0 & $8.5 \pm 0.1^{\mathrm{ab}}$ & $630 \pm 70.7^{\mathrm{ab}}$ & $5.36 \pm 0.8^{\mathrm{a}}$ & $8.53 \pm 0.4^{\mathrm{a}}$ & $0.62 \pm 0.04^{\mathrm{a}}$ \\
\hline $0+\mathrm{P}$ & $8.0 \pm 0.6^{\mathrm{ab}}$ & $636.7 \pm 145.7^{\mathrm{ab}}$ & $6.79 \pm 2.8^{\mathrm{a}}$ & $11.43 \pm 3.3^{\mathrm{ab}}$ & $0.59 \pm 0.11^{\mathrm{a}}$ \\
\hline 5 & $7.5 \pm 0.1^{\mathrm{ab}}$ & $508.7 \pm 99.4^{\mathrm{a}}$ & $4.91 \pm 1.26^{\mathrm{a}}$ & $8.49 \pm 1.20^{\mathrm{a}}$ & $0.58 \pm 0.12^{\mathrm{a}}$ \\
\hline 7.5 & $8.7 \pm 0.8^{\mathrm{ab}}$ & $790.0 \pm 71.0^{\mathrm{abc}}$ & $8.51 \pm 1.46^{\mathrm{a}}$ & $11.78 \pm 1.96^{\mathrm{ab}}$ & $0.72 \pm 0.04^{\mathrm{ab}}$ \\
\hline 10 & $9.5 \pm 0.4^{\mathrm{bc}}$ & $1010.0 \pm 14.1^{\mathrm{c}}$ & $16.28 \pm 3.6^{\mathrm{b}}$ & $17.48 \pm 0.51^{\mathrm{b}}$ & $0.93 \pm 0.07^{\mathrm{b}}$ \\
\hline $5+\mathrm{P}$ & $8.1 \pm 1.4^{\mathrm{a}}$ & $686.7 \pm 90.2^{\mathrm{ab}}$ & $7.02 \pm 1.60^{\mathrm{a}}$ & $10.41 \pm 1.78^{\mathrm{a}}$ & $0.67 \pm 0.06^{\mathrm{a}}$ \\
\hline $7.5+\mathrm{P}$ & $10.6 \pm 0.2^{\mathrm{cd}}$ & $985.0 \pm 70.71^{\mathrm{c}}$ & $14.47 \pm 0.46^{\mathrm{b}}$ & $27.7 \pm 0.56^{\mathrm{c}}$ & $0.52 \pm 0.06^{\mathrm{a}}$ \\
\hline $10+\mathrm{P}$ & $11.9 \pm 0.2^{\mathrm{d}}$ & $896.7 \pm 134.3^{\mathrm{bc}}$ & $17.23 \pm 1.21^{\mathrm{b}}$ & $25.73 \pm 3.93^{\mathrm{c}}$ & $0.68 \pm 0.13^{\mathrm{a}}$ \\
\hline
\end{tabular}

Values (mean \pm standard deviation); different letters in column indicate significant differences according to Tukey's B test $(p<0.05)$. S/R: shoot/root ratio.

\section{DISCUSSIONS}

Tests showed that applied treatment with mycorrhization and application of superabsorbent polymers during the seedlings growth in nursery, was an effective method for achieving better quality of $Q$. ilex and A. dasycarpum seedlings.

Mycorrhized $Q$. ilex seedlings displayed greater size (height and overall mass) than the untreated seedlings, characterized with developed mycorrhiza on the roots, after the first and third growing season.

Mycorrhization of $A$. dasycarpum seedlings showed a positive effect on seedling growth after application of inoculum in higher rate $(7.5$ and $10 \mathrm{ml}$ per plant), while application of lower investigated rate $(5 \mathrm{ml}$ per plant) seems to be inefficient.

In Montenegrin and Serbian nurseries, controlled mycorrhizal inoculation of seedlings has yet to become a common practice, but positive experiences with mycorrhization of conifer seedlings by autochthonous fungal isolates from this region have been already known for conifers (Lazarević, 2010; Lazarević et al., 2012 ), also as in case of conifer and hardwood mycorhization with commercial products (Lazarević, 2009).

The best known benefits from mycorrhiza are enhanced uptake of water and mineral nutrients, especially phosphorous and nitrogen (Bowen, 1973). These benefits are due in the part to the exploration of soil for nutrients and water by hyphae to the extent far beyond the capabilities of root alone. It is estimated that mycorrhizal fungi hyphae can explore volumes of soils hundreds to thousands of times greater than roots can (Castellano and Molina, 1989). Apart from nutritional benefits to their hosts, some mycorrhizal fungi can enable seedlings to withstand high soil temperatures and increase resistance to drought 
(Marx et al., 1982; Menkis, 2005). Of practical importance to nursery management, some mycorrhizal fungi can protect roots against certain pathogens, and can consequently improve growth of the seedlings (Smith and Read, 1997; Menkis, 2005). Hence, application of mycorrhiza in seedling production of plant material for afforestation is highly recommended.

Effect of the superabsorbent polymers on seedlings growth in this study differs depending on tree species, what is probably due to mycorrhizal characteristic for particular species. In case of ectomycorrrhizal $Q$. ilex, effect seems to be negative. Ectomycorrhiza is characterised by the distinct fungal sheath or mantle tissue that envelopes the feeder roots; often the fungal mycelium is emanating directly from the mantle and colonizing the soil or rooting substrate, where they absorb water and nutrients (Castellano and Molina, 1989; Smith and Read, 1997). It could be supposed that application of powdery polymers across the seedling root could delay formation of root hairs and mycorrhizal mantle, which can be developed as consequence of artificial inoculation, or by native spontaneous establishment of mycorrhizal fungi on seedlings roots. This way, proper formation of functional roots could be prevented and consequently, the development of seedlings slowed.

It is already shown that superabsorbent polymers were successfully used during the reforestation efforts with ectomycorrhizal host species, as Pinus nigra and P. sylvestris (Vilotić and Šijačić-Nikolić, 2009; Šijačić-Nikolić et al, 2010), but there superpolymers were added in planting holes. During the $Q$. ilex root examination in this trial, rests of polymers were present in small visible groups next to or along the roots. Hence, different methodologies of superabsorbent application in different plant species should be further investigated for final conclusions.

Positive effect on seedlings growth was recorded in case of application of superabsorbent polymers on mycorrhized $A$. dasycarpum. VA mycorrhiza appears strikingly different from ectomycorrhiza: it does not modify outer root's morphology and fungal component is invisible to the unaided eye. External mycorrhizal structures (mantle) are not developed in VA mycorrhiza, so potentially negative effect on their formation is not expected, so the polymers could react only beneficiary.

The basic characteristic of applied polymers are the organic origin, ability to absorb and retain the water about 300 times more than their own weight. From the chemical aspect they are inactive and $\mathrm{pH}$ neutral, have a capacity for remaining in the soil up to 3 years and to decompose into organic elements available to the plants. They are functioning on the principle that each free monomer of this substance absorbs the contacted water, retains and releases it when it is not available in the environment. This way, moisture is constant to the plants, regardless of the periodicity of watering or precipitation. In natural environment they are available to the plants throughout the period from about 12 months to several years, which depends on soil microorganisms causing biodegradation. Starch is one of the main polymer components. By 
decomposition it is transformed into starch sugars, thus increasing the nutritive value of the soil, acting as the source of food for the soil microorganisms. After polymer biodegradation, whatever remains in the soil, functions as soil additive to improve the aeration and other soil properties, creating the optimal conditions for more intensive development of the root system (Vilotić and Šijačić-Nikolić, 2009; Landis and Haase, 2012).

Application of polymers in agriculture is becoming increasingly diverse (Dragičević et al, 2008). In forestry, they were used as addition to substrate mixture for plant production and cultivation (Hederson and Hensley, 1986; Kjelgren at al., 1994; Kahl et al., 2000; Vilotić et al, 2006; Šijačić-Nikolić et al., 2010.), for seed germination (Hederson and Hensley, 1987, 1987a, Woodhouse \& Johnson, 1991; Šijačić-Nikolić et al., 2010), for soaking naked root seedlings in transport, for soil stabilization (Aly \& Letey 1989; El-Hady et al., 1981; ElSayed et al.,1991; Barvenik, 1994; Bouranius et al., 1995), for establishment of tree rows, shelterbelts and for reforestation of difficult, degraded terrains in climatically modified environmental conditions caused by drought and high temperatures (Cook \& Nelson, 1986; Callagan et al., 1989; Huttermann et al., 1990), also as for aforestation of cinder dumps, burnt, difficult and degraded areas (Vilotić and Šijačić, 2009).

VA mycorriza could be of special importance also for viticulture production, fruit growing and crop farming in different agricultural production systems in SEE region in different climate conditions, varying from Mediterranean and Submediterranean to dry continental climates, often characterized by extreme temperatures, low humidity, and low precipitation through the growing season, what is also true for application of superabsorbent polymers.
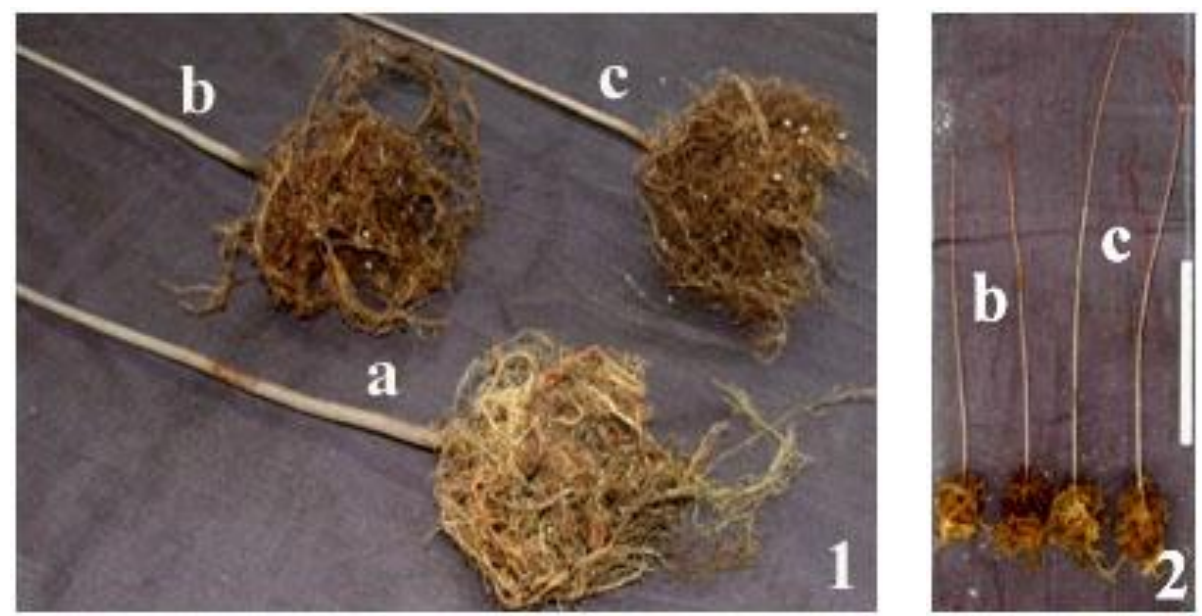

Figure 1 and 2. Inoculated Acer dasycarpum seedlings after $1^{\text {st }}$ growing season. a) 5 $\mathrm{ml}$ of Aegis/seedling; b) $7.5 \mathrm{ml}$ of Aegis /seedling; c) $10 \mathrm{ml}$ of Aegis /seedling 


\section{CONCLUSIONS}

Nursery production in open field conditions in Podgorica, also as in whole Submediterranean and Mediterranean region is faced with problems of too high summer temperatures and insolations, and consequently with fast drying of substrates. This effect could be mitigated by application of mycorrizal symbionts and superabsorbent polymers. In experimental trials it was shown that mycorrhization of forest seedlings could be assumed as successful. Differences between treated and control seedlings depend on plant species and fungal symbiont.

Mycorrhization of $Q$. ilex seedlings with $1 \mathrm{ml}$ of (ECM) ectomycorrhizal inoculum $\left(10^{7}\right.$ propagules) was effective, while validity of polymer application is still under the study. Optimal application dose of VA mycorrhizal inoculum for A. dasycarpum was determined on $7.5 \mathrm{ml} / \mathrm{seedling}$ (c.ca 750 infective propagules/plant). The increase of $A$. dasycarpm plant size was evident (1.5 times compared to untreated), and in combination with polymers it was more than 2 times.

\section{ACKNOWLEDGEMENTS}

This research was supported by grants from the Ministry of Science and Ministry of Agriculture and Rural Development of Montenegro, project contract $\mathrm{nmb}$ 01-406/01-558 and by the grants from the Ministry of Education and Science of the Republic of Serbia, projects TR 37008 and TR 31041.

\section{REFERENCES}

Ally, S.M. \& Letey, J. (1989): T he effect of two polymers and water qualities of dry cohesive strength of three soils. Soil Science Society of America Journal 53: 255-259.

Barvenik, F.W. (1994): Polyacrilamide characteristics related to soil aplications. Soil Science 158 (4):235-243.

Bathlenfalvay, G.J. (1992): Mycorrhiza in the agricultural plant-soil system, Sybiosis, 14:413-425.

Bouranis, D.L., Theodoropoulos A.G., Drossopoulos J.B. (1995): Desogning syntetic polymers as soil conditioners. Communications in Soil Sciences and Plant Analysis 26 (9 \& 10): 1455-1480.

Bowen, G.D. (1973): Mineral nutrition of ectomicorrhizae, in Ectomycorrhiza, Their Ecology and Physiology., Ed. Marx G.C., Kozlowsky T.T. AP, 151-205.

Callagan, T.V., Lindlay D.K., Ali, O.M., Abd El Nour, H., Bacxon P.J. (1989): The effect of water-absorbing synthetic polymers on the stomatal conductance, growth and survival of transplanted Eucaliptus microtheca seedlings in the Sudan. Journal of Applied Ecology 26: 663-672.

Castellano, M.A., Molina, R. (1989). Mycorrhizae. In: The Container Tree Nursery Manual, Vol 5. Agric. Handbk. 674. (Landis, T.D., Tinus, R.W., McDonald, S.E., Barnett, J.P. eds.). U.S. Department of Agriculture, Forest Service, Washington DC, USA, 101-167.

Claro V., Santos L.M., Palma A., Borges AE., 1998: The influence of cotainer type in the production of some species. Propagation of ornamental plants, IPPS, IPPS in Bulgaria, 3rd International Conference, Forest University, Sofia, pp.33-38. 
Corcobado Tamara, Cubera Elena, Juárez,Enrique, Moreno Gerardo, Solla Alejandro, 2014. Drought events determine performance of Quercus ilex seedlings and increase their susceptibility to Phytophthora cinnamomi. Agricultural \& Forest Meteorology. July 2014, Vol. 192-193, p1-8. 8p

Cook, D.F. \& Nelson S.D. (1986): Effect of polyacrileamide on seedling emergence in crust forming soils. Soil Science 141 (5):328-333.

Dragičević V., Sredojević S., Kresović, B. Lazić-Jančić, V. (2008): The application of Super-Hydro-Grow polymer instead of irrigation. 4th Croatia and 3rd Interntional Symposium of Agriculture, 18-21 February Opatia, Croatia, Book of Abstracts, p.3.

El-Hady, O.H., Tayel, M.Y., Lofty A.A. (1981): Super Gel as a soil conditioner II-Its effect on plant growth, enzymes activity, water use efficiency and nutrient uptake. Acta. Hort. 119:257-265.

El-Sayed, H., Kirkwood R.C., Graqham N.B. (1991): The effect of a hydrogel polymer on the growth of certain horticultural crops under saline conditions, Journal of Experimental Botany 42 (240):891-899.

Hederson, J.C. \& Hensley, D.L. (1986): Efficacy of a hydrophilic gel as a transplant aid. Hort. Science 21 (4):991-992.

Hederson, J.C. \& Hensley, D.L. (1987): Effect of a hydrophilic gel on seed germination of three tree species. Hort. Science 22 (3):450-452.

Hederson, J.C. \& Hensley, D.L. (1987a): Do hydrophylic gel improve germination and survival? American Nurseryman 166(4): 189-190.

Huttermann, A., Zommorodi M., Reise K. (1990): Addition of hydrogels to soil for prolonging the survival of Pinus halepensis seedlings subjected to drought. Soil and Tillage Research 50: 295-304.

Jovanović, B. (2007). Dendrology, Univerzity in Belgrade, Faculty of Forestry, Belgrade, 536 (in Serbian).

Kahl, R.G., Kluge, R., Thomas, S. (2000): Evaluation of an attempt to cultivate shrubs and trees on a heap of potash mine. Landscape and Urban Planing 51:109-112.

Kjelgren, R., Cleveland B., Foutch, M. (1994): Establishment of white oak seedlings with tree post-plant handling methods on deep tilled minesoil during reclamation. Journal of Environmental Horticulture 12(2): 100-103.

Landis, D.H. (1989). Disease and Pest Management, In: The Container Tree Nursery Manual, Vol 5. Agric. Handbook. 674. (Landis, T.D., Tinus ,R.W., McDonald, S.E., Barnett, J.P. eds.). U.S. Department of Agriculture, Forest Service, Washington DC, USA. 1-99.

Landis T.D., Haase D.L. (2012): Applications of Hydrogels in the nursery and during outplanting, In: Haase D.L, Pinto, J.R., Riley, L.E, technical coordinators. National proceedings: Forest \& Conservation Nursery Associations-2011. Fort Collins (Co):USDA Forest Service, Mountain research station. Proceedings RMRS-P-68. pp.53-58.

Lazarević, J. (2009). Possibilities of hardwood and coniferous seedling mycorrhization in the field conditions in Podgorica, International Conference "Forestry in achieving millennium goals", Institute of Lowland forestry and Enviroment, Novi Sad, Proceedings, pp. 331-337.

Lazarević, J. (2010): Mycorrhization of containerized Pinus nigra seedlings with autochthonous Pisolithus arrhizus, Proceedings First Serbian Forestry Congress "Future with Forests", Faculty of Forestry University of Belgrade, Belgrade (Serbia) 11-13 November, 348-354. 
Lazarević J., Keča, N., Martinović, A. (2012): Mycorrhization of containerized Pinus nigra seedlings with Suillus granulatus under open field conditions, Forest Systems 2012 21(3),498-507

Menkis, A. (2005): Root asociated fungi of conifer seedlings and their role in afforestation of agricultural land, Doctoral thesis No.2005:106, Swedish University of Agricultural Sciences, Uppsala.

Marx DH, Ruehle JL, Kenney DS, Cordell CE, Riffle J.W, Molina R.J, et al. (1982): Commercial vegetative inoculum of Pisolithus tinctorius and inoculation techniques for development of ectomycorrhizae on container-grown tree seedlings. For Sci 28/2, 373-400.

Molina, R. (1979). Ectomycorrhizal inoculation of containerized Douglas-fir and londgepole seedlings with six isolates of Pisolithus tinctorius. Forest Science 25, 585 590.

Pera J, Parlade J. 2005. Inoculacion controlada con hongos ectomicorricicos en la production de planta destinada a repoblaciones forestales:estado actual en Espana. Invest Agrar Sist Recur For 14, 419-433.

Rincon A., Parlade J, Pera J(2005): Effects of ectomycorrhizal inoculation and the typeof substrate on mycorrhization, growth and nutrition of containerised Pinus pinea L. seedlings produced in a commercial nursery. Ann. For. Sci 62:1-6

Rincon, A., de Felipe, M.R., Fernandez-Pascual, M. (2007). Inoculation of Pinus halepensis Mill. with selected ectomycorrhizal fungi improves seedling establishment 2 years after planting in degraded gypsum soil. Mycorrhiza 18, 23-32.

Ruiz-Diez, B., Rincon, A.M., de Felipe, M.R., Fernandey-Pascual, M. (2006). Molecular characterisation end evaluation of mycorrhiyal capacity of Suillus isolates from Central Spain for the selection of fungal inoculants. Mycorrhiza 16, 465-474.

Sánchez-Andrés, R., Sánchez-Carrillo, S., Benítez, M., Sánchez-López, A. (2006): Tillage induced differential morphometric responses and growth patterns in afforestation with Quercus ilex. Soil \& Tillage Research 90 (1/2):50-62.

Scarascia-Mugnozza, G., Oswald, H., Piussi, P., Radoglou, K.et al. (2000): Forests of the Mediterranean region: gaps in knowledge and research needs, Forest Ecology and Management 132:97-109.

Smith, S., Read D.J. (1997). Mycorrhizal symbiosys. London UK: Academic press, 605.

Vilotić D., Vukojevac, S., Šijačić-Nikolić M. (2006): Effect of superabsorbent polymers on development of Paulownia elongata seedlings, Proceedings of the IUFRO Division 2 Join Conference: Low input breeding and genetic conservation of forest tree species, Antalya, Turkey, 9-13. October (ed: Fikret Isak), p.4.

Vilotić, D. and Šijačić-Nikolić M. (2009): Modern technologies in burnt area reforestation. International Conference "Forestry in achieving millennium goals", Institute of Lowland forestry and Enviroment, Novi Sad, Proceedings, pp. 263-268.

Vukićević E. (1974).-Decorative dendrology, Naučna knjiga, Belgrade (in Serbian).

Woodhouse, J. \& Johnson, M.S. (1991): Effect of superabsorbent polymers on survival and growth of crop seedlings. Agricultural Water Management 20: 63-70.

Šijačić-Nikolić, M., Vilotić, D., Milovanović, J., Veselinović, M., Stanković, D. (2010). Application of superabsorbent polymers in the production of Scotch pine (Pinus sylvestris L.) and Austrian pine (Pinus nigra Arn.) seedlings. Fresenius Environmental Bulletin 19, 1180-1185. 